\title{
Pergulatan di Balik Frekuensi: Studi Deskriptif Radio Komunitas di Jawa Tengah
}

\author{
Andreas Ryan Sanjaya \& Andreas Pandiangan \\ Universitas Katolik Soegijapranata \\ Jalan Pawiyatan Luhur IV/1, Semarang \\ Email: ryansanjaya@unika.ac.id; pandiangan@unika.ac.id
}

\begin{abstract}
ABSTRAK: Studi ini secara spesifik mengambil tema radio komunitas. Secara umum, radio mengalami dinamika pasang surut karena berbagai persoalan yang dihadapinya. Secara khusus, radio komunitas juga mengalami persoalan yang selalu berkaitan dengan ciri-ciri khusus yang membedakan dirinya dari radio komersil. Peneliti menggali informasi dari 20 (dua puluh) pengelola radio komunitas yang tergabung dalam Jaringan Radio Komunitas Indonesia (JRKI) di Jawa Tengah. Penelitian dilakukan menggunakan pendekatan studi kasus. Data didapatkan melalui wawancara kepada setiap pengelola radio komunitas tersebut. Secara ringkas ditemukan beragam persoalan radio komunitas yang berakar pada beragamnya jenis dan motif dari komunitas tersebut, misalnya petani dan warga daerah rawan bencana. Radio komunitas juga menghadapi persoalan manajemen, pendanaan, partisipasi masyarakat, serta dukungan dari pihak ketiga.
\end{abstract}

Kata kunci: radio komunitas, JRKI Jawa Tengah, persoalan manajerial

ABSTRACT: This study specifically tooks the theme of community radio. In general, radio faces dynamics because of the various problems. In particular, community radio also faces problems that are always related to special caracter that distinguish itself from commercial radio. The researcher gathered information from 20 community radio managers who were members of the Indonesian Community Radio Network (ICRN) in Central Java Province. In summary, a variety of community radio problems were found that were rooted in various types and motives of the community, for example farmers and residents of disaster-prone areas. Community radio also faces management, funding, community participation, and support from third parties.

Keywords: community radio, Central Java ICRN (JRKI Jawa Tengah), managerial problem 


\section{PENDAHULUAN}

Sebagaimana terjadi di negara lain, kehidupan media massa di Indonesia mengalami pasang surut seiring perubahan kondisi sosial, politik, dan perkembangan teknologi di negara tersebut. Kendati sejak awal mengklaim diri sebagai negara yang berasaskan demokrasi-yang salah satu semangatnya adalah menjamin kebebasan berpendapat-media massa justru mengalami masa-masa kelam sejak pemerintahan Presiden Soekarno maupun penguasa setelahnya, yaitu Presiden Soeharto. Ruang gerak organisasi media massa dibatasi melalui berbagai peraturan yang mengekang kebebasan pers.

Persoalan lain dari pers yang terpenjara oleh peraturan ketat tersebut adalah adanya hak masyarakat yang tidak terpenuhi dengan optimal, yaitu hak untuk mengetahui. Padahal hak untuk mengetahui informasi ini telah mendapatkan pengakuan secara universal sebagai salah satu hak paling mendasar yang melekat pada setiap individu manusia. Oleh karenanya, hak tersebut harus dipenuhi dan dihormati oleh siapapun, termasuk oleh negara (Saddu, 2016).

Kehadiran radio komunitas (rakom) di Indonesia secara umum tak dapat dilepaskan dari semangat demokratisasi di berbagai bidang, termasuk media massa. Pada era Orde Baru tercatat 289 media cetak, 6 stasiun televisi, dan 740 radio. Hanya satu tahun setelah reformasi jumlah media massa melonjak begitu tinggi, yaitu lahir 1.389 media cetak baru, 60 stasiun televisi, serta 2.000 radio berizin (Antara, 2008). Masduki (2004) menyebutkan setidaknya ada dua dasar rasional terkait kehadiran rakom ini. Pertama, kehadiran rakom di tengah masyarakat menyadarkan kembali akan adanya frekuensi sebagai ranah publik (public domain) yang sejatinya dapat diakses oleh semua lapisan masyarakat. Sebelumnya frekuensi milik publik ini dimonopoli oleh radio milik pemerintah dan radio milik swasta yang memiliki kepentingan yang berbeda. Kedua, masih terkait dengan dasar pertama, kehadiran rakom dapat mengubah persepsi buruk warga akan radio pada zaman Orde Baru. Secara umum, media saat itu tak dapat lepas dari pengawasan ketat pemerintah. Secara khusus, radio pada saat itu dikuasai oleh elitis, baik oleh pemerintah dengan kepentingan propaganda ideologi politiknya, maupun oleh oleh pihak swasta yang mengutamakan keuntungan komersial yang didapatkan. Pada saat itu warga dianggap tidak dapat memenuhi hak sosial politiknya dengan tidak dapat memiliki frekuensi jaringan radionya sendiri.

Maka dengan memiliki jaringan radio sendiri, warga dapat menolak monopoli informasi yang hanya dari sumber-sumber tertentu saja. Warga dapat mendapatkan-dan menyebarkan-informasi yang spesifik, informasi yang betul-betul mereka butuhkan, dari dan melalui rakom ini. Dapat dipahami ketika isu mengenai radio komunitas ini kemudian menjadi isu yang relatif diminati oleh berbagai pihak, terutama yang berkaitan dengan gerakan sosial maupun studi media. Dengan demikian, penting kiranya bagi akademisi ilmu komunikasi untuk terus memberikan perhatian pada studi-studi tentang media komunitas, yang dalam konteks penelitian ini adalah radio komunitas. Terdapat dua alasan penting mengapa studi radio komunitas perlu terus dihidupkan. Pertama, radio komunitas memiliki karakteristik yang berbeda dari radio publik dan radio komersil. Perbedaan karakteristik dan peraturan atasnya tersebut tentu menghasilkan 
persoalan dan dinamika yang berbeda pula, dan temuan itu akan berarti bagi perkembangan media massa secara umum. Kedua, meneliti media massa adalah meneliti masyarakat itu sendiri. Kondisi media massa pada sebuah komunitas masyarakat adalah cerminan dari masyarakat yang dilayani melalui kehadirannya.

Berangkat dari latar belakang tersebut, peneliti mengungkapkan dua rumusan masalah yang dijawab melalui penelitian ini: 1) Apa saja persoalan yang dihadapi oleh radio komunitas? dan 2) Bagaimana pengelola radio komunitas menghadapi persoalan tersebut?

Penelitian mengenai radio komunitas, terutama radio komunitas yang tergabung dalam Jaringan Radio Komunitas Indonesia (JRKI) Jawa Tengah, masih sepi peminat. Maka penelitian ini dilakukan dengan tujuan mendapatkan temuan awal yang dapat dikembangkan melalui penelitian-penelitian berikutnya. Temuantemuan penting berupa persoalan yang dihadapi radio komunitas ini juga dapat dijadikan bahan pertimbangan dalam penyusunan programprogram pengabdian kepada masyarakat.

\section{TINJAUAN PUSTAKA}

Pada awalnya radio digunakan untuk mengirim pesan-pesan strategis dalam masa perang. Seiring berjalannya waktu radio berkembang pesat menjadi alat pemenuhan kebutuhan informasi, hiburan, serta pendidikan. Dalam konteks penelitian ini radio komunitas dipandang sebagai alat untuk menguatkan identitas dan terutama memenuhi kebutuhan informasi dari setiap anggota komunitas yang menjadi dasar pembentukan radio tersebut.
Romli (2009) menyebutkan radio sebagai media massa yang bersifat auditif. Artinya, informasi dan pesan yang disampaikan melalui radio berbentuk getaran suara yang kemudian ditangkap oleh khalayak melalui indera pendengaran. Kegiatan mendengarkan informasi melalui radio ini ternyata bukan hanya digemari oleh generasi tua (mengingat sejarah radio yang panjang), namun juga diminati oleh anak muda generasi milenial.

Temuan riset Nielsen Radio Audience Measurement pada kuartal ketiga tahun 2016 menunjukkan $57 \%$ dari total pendengar radio adalah generasi Z (Lubis, 2016). Hal ini adalah angin segar bagi pendengar radio karena berarti mereka adalah konsumen masa depan. Riset tersebut menunjukkan empat dari sepuluh pendengar radio mendengarkan radio melalui perangkat yang bersifat personal, yaitu telepon seluler.

Dengan kehadiran teknologi Internet yang memungkinkan setiap orang melakukan banyak hal, patut diduga sebagian besar waktu mengakses media digunakan untuk mengakses media daring. Namun riset tadi menunjukkan hal yang menarik karena durasi mendengarkan radio per minggu bertambah dari tahun ke tahun. Pada tahun 2014 pendengar radio menghabiskan waktu 16 jam per minggunya untuk mendengarkan radio. Angka ini meningkat menjadi 16 jam 14 menit pada tahun 2015, dan 16 jam 18 menit pada tahun 2016. Radio lebih bersifat portabel atau dapat didengarkan di mana saja. Dengan mobilitas masyarakat yang kian tinggi, ternyata riset tersebut menemukan 96 persen pendengar radio mengakses media tersebut dari rumah. Hal tersebut menandakan

${ }^{2}$ Selanjutnya disebut sebagai PP No. 51/2005 
radio digunakan oleh komunitas masyarakat yang tinggal di daerah tertentu. Maka penelitian ini menemukan relevansinya.

Radio yang didengarkan oleh khalayak tersebut adalah bagian dari jasa penyiaran. Undang-Undang Republik Indonesia No. 32 Tahun 2002 tentang Penyiaran membagi jasa penyiaran

Jenis penelitian yang digunakan dalam penelitian ini adalah kualitatif. Penelitian kualitatif berarti penelitian yang menyoroti keterkaitan antar gejala, makna gejala, deskripsi yang utuh, serta menggunakan uraian yang tebal (thick description) untuk memperoleh gambaran yang lengkap (Imran, 2015). Sementara, metode penelitian yang digunakan adalah pendekatan studi kasus. Yin (sebagaimana dikutip Rianto, 2008) mendefinisikan studi kasus sebagai suatu penelitian empiris yang menyelidiki fenomena dengan konteks kehidupan nyata. Metode studi kasus ini relevan untuk menjawab pertanyaan dalam penelitian karena sifatnya yang spesifik. Sifat tersebut dianggap mampu memberi gambaran secara rinci mengenai latar belakang, sifat, serta karakter yang ditemukan dalam subyek penelitian.

Data yang ada dalam penelitian ini dibagi menjadi dua, yakni data primer dan data sekunder. Data primer didapatkan dengan menggunakan teknik observasi lapangan. Wimmer \& Dominick (2011) menekankan bahwa teknik observasi lapangan ini memiliki kelebihan yang paling utama, yaitu mengumpulkan data awal dalam suatu penelitian. Dalam penelitian ini peneliti turun ke lapangan langsung untuk mewawancarai dua puluh pengurus radio-radio komunitas yang tergabung dalam JRKI Jawa Tengah. Untuk mendapatkan data primer, peneliti melakukan wawancara kepada narasumber dengan bantuan beberapa asisten peneliti yang sebelumnya telah diberi pembekalan dan membawa panduan wawancara, sedangkan data sekunder didapatkan dengan memanfaatkan data radio komunitas yang dimiliki oleh masing-masing pengelola radio komunitas yang menjadi subyek penelitian.

Proses wawancara dilakukan dengan serentak pada waktu dan tempat yang sama di Semarang, sehingga proses pencarian data menjadi lebih efisien dari segi waktu maupun biaya. Adapun daftar radio komunitas yang menjadi subyek penelitian adalah sebagai berikut:

Tabel 1. Daftar Radio Komunitas

\begin{tabular}{|c|l|c|l|l|}
\hline $\begin{array}{c}\text { No } \\
.\end{array}$ & \multicolumn{1}{|c|}{ Rakom } & Frekuensi & \multicolumn{1}{|c|}{$\begin{array}{c}\text { Target } \\
\text { Pendengar }\end{array}$} & \multicolumn{1}{|c|}{ Kota / Kabupaten } \\
\hline 1 & Mentari FM & 107,8 & Umum & Kab. Banjarnegara \\
\hline 2 & Banyumas & 107,7 & Umum & Kab. Banyumas \\
\hline
\end{tabular}




\begin{tabular}{|c|c|c|c|c|}
\hline 3 & Ilham FM & 107,8 & Umum & Kab. Batang \\
\hline 4 & Rasta FM & 107,7 & Umum & Kab. Blora \\
\hline 5 & Merapi Merbabu & 107,8 & Petani & Kab. Boyolali \\
\hline 6 & Swara Pusaka & 107,7 & Pedagang & Kab. Kendal \\
\hline 7 & Suara Bahari & 107,8 & Nelayan & Kab. Kendal \\
\hline 8 & Sanggar Seni & 107,4 & Umum & Kab. Klaten \\
\hline 9 & Gema Swara FM & 107,6 & Umum & Kab. Magelang \\
\hline 10 & K FM & & Umum & Kab. Magelang \\
\hline 11 & PPK FM Sragi & 107,7 & Buruh & Kota Pekalongan \\
\hline 12 & Stara FM & 107,8 & Umum & Kota Pekalongan \\
\hline 13 & Sahiba FM & 107,7 & Umum & Kota Pekalongan \\
\hline 14 & NMI FM & 107,8 & Pedagang, Petani & Kab. Pemalang \\
\hline 15 & Monalisa FM & 107,8 & Penjahit & Kab. Pemalang \\
\hline 16 & $\begin{array}{l}\text { Radioland Swara } \\
\text { Swadaya }\end{array}$ & On Land & $\begin{array}{l}\text { Pedagang dan } \\
\text { pengunjung }\end{array}$ & Kab. Sragen \\
\hline 17 & Kalimas FM & 107,7 & $\begin{array}{l}\text { Pengrajin } \\
\text { Gentang, Petani, }\end{array}$ & Kab. Sukoharjo \\
\hline 18 & Kemeng FM & 107,2 & Umum & Kota Pekalongan \\
\hline 19 & JM Radio & 107,7 & Umum & Kota Semarang \\
\hline 20 & Gapura Pasar Klewer & On Land & $\begin{array}{l}\text { Pedagang dan } \\
\text { pengunjung }\end{array}$ & Kota Surakarta \\
\hline
\end{tabular}

Sumber: Olahan Data Peneliti, 2018

\section{HASIL DAN PEMBAHASAN}

Bagian hasil pembahasan ini dibagi menjadi dua bagian besar, yakni ragam persoalan radio komunitas dan pola manajemen radio komunitas. Persoalan dalam radio komunitas ini ditemukan dalam wawancara kepada dua puluh pengelola radio komunitas yang dilakukan peneliti. Temuan persoalan radio komunitas ini berfungsi untuk mengidentifikasi hambatan sekaligus peluang yang dimiliki oleh radio komunitas untuk menyelesaikan persoalan itu sendiri. Sementara pola manajemen radio komunitas yang juga ditemukan dalam wawancara turut diuraikan untuk menjelaskan bagaimana persoalan-persoalan tersebut memiliki peluang untuk diselesaikan dengan menggunakan pendekatan pengelolaan.

\section{Ragam Persoalan Radio Komunitas}

Berdasarkan hasil wawancara yang dilakukan, paling tidak ditemukan empat persoalan yang dihadapi radio komunitas, yaitu 1) manajemen, 
2) pendanaan, 3) partisipasi masyarakat, dan 4) dukungan dari pihak ketiga.

Dalam bidang manajemen radio komunitas, persoalan pertama yang dihadapi adalah penguasaan keterampilan dari pengelola radio komunitas. Hal ini dapat dipahami mengingat hampir semua pengelola radio komunitas tidaklah berasal dari pihak profesional radio penyiaran. Sebagian besar dari mereka berasal dari komunitas yang membutuhkan informasi untuk pengembangan komunitas itu sendiri. Contohnya adalah radio komunitas Radio Rasta Blora yang berlokasi di Jl. Raya Blora Cepu Km 5, Blora. Nama "Rasta" sendiri merupakan singkatan dari Swara Tani. Radio Rasta didirikan komunitas "Rastafara", sebuah komunitas petani yang sebelumnya telah tergabung dalam kelompok pendengar siaran pedesaan. Selain itu ada juga Radio Kalimas FM yang berlokasi di Kabupaten Sukoharjo. Radio yang telah mengudara sejak 2006 ini didirikan oleh pengrajin gentan dan petani.

Persoalan kedua dalam bidang manajemen adalah keterbatasan waktu dan

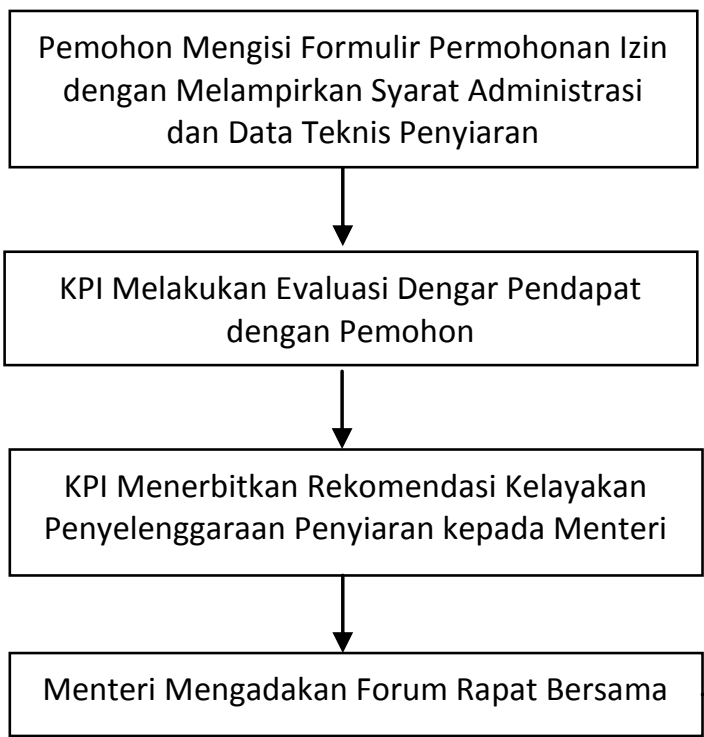

pikiran untuk mengelola radio komunitas. Sebagian besar pengelola radio komunitas memiliki pekerjaan lain yang utama dan menyita waktu lebih banyak. Misalnya Radio Mentari FM yang merupakan radio komunitas yang berasal dari impian komite sekolah SD Negeri 1 Giritirta, Kecamatan Pejawaran, Kabupaten Banjarnegara. Radio ini berada di lingkungan sekolah, dan oleh karenanya, mengusung tema-tema pendidikan. Kendati memiliki tema yang baik dan pendengar yang spesifik, radio ini tentu saja baru mengudara setelah kegiatan sekolah berakhir.

Persoalan ketiga dalam manajemen yang dihadapi oleh pengelola radio komunitas adalah perizinan. Sebenarnya peraturan mengenai perizinan radio komunitas ini sudah tertera dengan cukup jelas dalam Peraturan Pemerintah Republik Indonesia Nomor 51 Tahun 2005 tentang Penyelenggaraan Penyiaran Lembaga Penyiaran Komunitas. Adapun prosedur yang perlu dilalui oleh pengelola radio komunitas untuk mendapatkan perizinan dari menteri dapat dilihat pada bagan berikut:

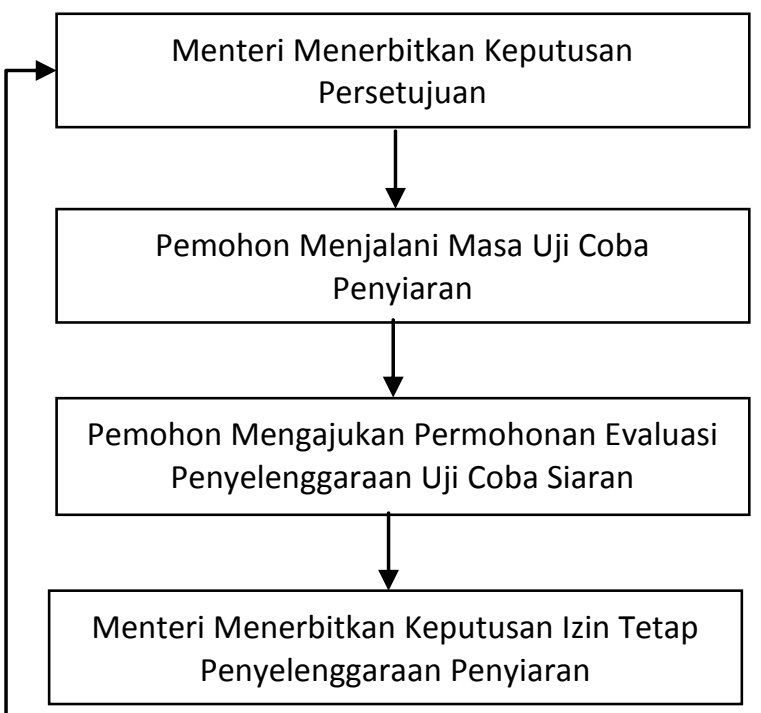

Bagan 1. Prosedur Mendapatkan Perizinan Penyelenggaraan Siaran Sumber: Diolah dari PP No. 51/2005 
Hal yang menjadi persoalan dalam memperoleh izin ini tertera pada Pasal 2 Ayat (2) yang menyebutkan:

Lembaga Penyiaran Komunitas didirikan dengan persetujuan tertulis:

a. paling sedikit $51 \%$ (lima puluh satu perseratus) dari jumlah penduduk dewasa atau paling sedikit 250 (dua ratus lima puluh) orang dewasa; atau

b. paling sedikit $51 \%$ (lima puluh satu perseratus) dari jumlah penduduk dalam wilayah jangkauan siaran di daerah dengan sebaran penduduk tidak padat, terpencil, atau di wilayah perbatasan.

Persetujuan secara tertulis ini tidak mudah untuk didapatkan terutama untuk radio komunitas yang tidak melayani masyarakat yang bermukim di daerah tertentu, misalnya Radioland Swara Swadaya di Sragen dan Gapura Pasar Klewer (Surakarta). Kedua radio ini memiliki dua persamaan, yaitu melayani kebutuhan informasi pedagang dan pengunjung pasar (Pasar Bunder Sragen dan Pasar Klewer), serta mereka sama-sama tidak mengudara menggunakan frekuensi melainkan melalui pengeras suara yang diletakkan di titik-titik tertentu di pasar tersebut. Selain itu kendala perizinan yang juga dialami oleh radio komunitas berada pada Pasal 2 Ayat (4) yang berbunyi sebagai berikut:

Lembaga Penyiaran Komunitas yang didirikan sebagaimana dimaksud pada ayat (1) tidak mengatasnamakan

2 Selanjutnya disebut sebagai PP No. 51/2005

3 Selanjutnya disebut dengan UU No. 32/2002 suku, agama, ras, dan golongan tertentu/non partisan.

Persoalannya adalah ada beberapa radio komunitas yang memang berdiri berdasarkan kelompok agama tertentu. Radio-radio komunitas tersebut memang membawa misi dakwah. Dalam KBBI versi daring dakwah diartikan sebagai "penyiaran agama dan pengembangannya di kalangan masyarakat; seruan untuk memeluk, mempelajari, dan mengamalkan ajaran agama."

Ragam persoalan yang kedua adalah persoalan pendanaan. Dalam Undang-Undang Republik Indonesia Nomor 32 Tahun 2002 tentang Penyiaran Pasal 23 Ayat (2) disebutkan "Lembaga Penyiaran Komunitas dilarang melakukan siaran iklan dan/atau siaran komersial lainnya, kecuali iklan layanan masyarakat". Artinya sumber dana untuk kegiatan penyiaran radio komunitas hanya boleh dari sumbangan, hibah, sponsor, serta sumber lain yang sah dan tidak mengikat. Sumbangan, hibah, maupun sponsor juga dilarang berasal dari pihak asing.

Secara umum, pengelola radio komunitas mengaku mendapatkan sumber pendanaan paling besar dari iklan masyarakat yang diperoleh dari dinas-dinas/SKPD Pemerintah Daerah dan Instansi Pusat. Misalnya, yang seringkali disebutkan adalah dari Badan Kependudukan dan Keluarga Berencana Nasional (BKKBN) yang mengiklankan programprogram kerja mereka. Selain itu, ada juga bantuan pendanaan untuk kegiatan pelatihanpelatihan yang diikuti oleh pengelola radio komunitas.

Kendati demikian, ada juga radio komunitas yang 
menjadikan sumbangan pemilik sebagai sumber pendanaan yang utama, misalnya Gapura Pasar Klewer. Berdasarkan wawancara yang dilakukan, pengelola radio tersebut mengaku banyak menggunakan dana dari pemilik langsung dalam kegiatan operasional dan untuk memberi upah pada pekerjanya.

Sumber dana lain yang digunakan oleh radio ini adalah hasil dari penjualan kupon kepada para pedagang pasar sebagai pendengar dari radio tersebut. Sistemnya adalah pengelola menawarkan kupon-kupon seharga seribu rupiah kepada pedagang Pasar Klewer. Kuponkupon tersebut diisi dengan permintaan lagu dan ucapan salam kepada pedagang-pedagang lain yang ada di pasar tersebut. Pengelola memandang cara ini adalah cara yang efektif, baik untuk mengumpulkan dana maupun sebagai wadah interaksi antarpedagang pasar untuk saling memberikan semangat.

Selain menjual kupon tersebut, beberapa tahun lalu radio Gapura Pasar Klewer juga pernah membuka peluang pedagang pasar untuk datang ke studio lantas ikut menyumbang suara mereka (karaoke) dan diperdengarkan di seluruh penjuru pasar. Tentu saja pedagang juga membayarkan sejumlah uang untuk memperdengarkan suara mereka melalui radio tersebut. Namun cara ini sudah dihentikan oleh pengelola radio karena alasan teknis, yaitu tidak setiap pedagang pasar memiliki kualitas vokal yang nyaman untuk didengar oleh khalayak. Selain itu juga pengelola juga tidak dapat membatasi pilihan lagu yang hendak dinyanyikan oleh pedagang tersebut. Berdasar hasil wawancara, peluang karaoke ini dihentikan dan pengelola memilih lagu-lagu yang hanya bernuansa edukasi dan memberikan suntikan semangat bagi para pedagang pasar.

Ragam persoalan yang ketiga adalah keterbatasan partisipasi masyarakat (sebagai khalayak pendengar radio) atas radio komunitas tersebut. Hal yang dimaksud dengan partisipasi masyarakat ini tidaklah terbatas pada sumbangan (pendanaan) saja, melainkan juga pada upaya untuk menjadikan radio ini sebagai salah satu ruang publik. Ruang publik yang dimaksud adalah forum di mana masyarakat mampu memberikan pandangan dan gagasan mereka atas permasalahan-permasalahan yang terjadi di komunitas tempat mereka hidup. Sebagian besar partisipasi masyarakat dalam radio komunitas adalah pada permintaan lagu yang diputar saja.

Kendati demikian, ada satu radio komunitas yang berdasarkan interpretasi peneliti terhitung matang dan progresif dalam menjalankan fungsinya, yaitu Radio Merapi Merbabu Community. Radio yang berlokasi di Desa Samiran, Kecamatan Selo, ini didirikan oleh aktivis petani yang berada di lereng Gunung Merapi dan Gunung Merbabu dengan tujuan untuk melakukan pendidikan bagi petani. Ditilik dari Anggaran Dasar/Anggaran Rumah Tangga (AD/ART) yang telah disusun, radio $M M C$ didirikan agar berperan mewujudkan masyarakat yang berdaya melalui kebebasan informasi, kebebasan berbicara dan berekspresi secara bertanggungjawab sehingga dapat mengembangkan diri dan lingkungannya serta berpartisipasi dalam proses pengambilan kebijakan untuk meningkatkan kesejahteraan dan kualitas hidupnya.

\footnotetext{
* Selanjutnya disebut dengan MMC.
} 
pelajar, misalnya, latar belakang budaya dan kondisi sosial di belakang radio komunitas tersebut tetaplah beragam. Keberagaman itu pula yang turut membentuk keberagaman pola pengelolaan radio komunitas. Peneliti mengidentifikasi tiga pola pengelolaan, yakni:

1. Radio komunitas yang memiliki struktur pengelolaan yang relatif terinci. Struktur yang rinci tersebut di antaranya tersedia Pendiri, Pimpinan, Pelaksna. Beberapa radio komunitas bahkan telah memiliki $A D /$ ART yang menuliskan rincian wewenang dan tugas masing-masing pengelola. Rincian tersebut perlu untuk disusun sehingga tidak terjadi penugasan ganda untuk seorang personil pengelola.

2. Radio komunitas yang memiliki struktur pengelolaan yang semi terinci. Pada pola ini tersedia Pendiri, Pimpinan, Pelaksana tetapi terjadi penugasan personil yang rangkap seperti menjadi Pendiri sekaligus Pelaksana.

3. Radio komunitas yang memiliki struktur pengelolaan yang sederhana. Pada pola ini hanyalah tersedia struktur Pendiri dan Pelaksana. Sama seperti pola pengelolaan sebelumnya, terjadi rangka pekerjaan antara Pendiri dan Pelaksana.

Ragam pola pengelolaan yang ditemukan pada dua puluh radio komunitas ini akan berakibat pada pengelolaan kegiatan siaran, penggalian dana operasional, hingga pengembangan kegiatan rakom baik on air dan atau off air.

\section{KESIMPULAN}

Radio komunitas yang tergabung dalam JRKI Jawa Tengah merupakan anak kandung dari dinamika masyarakat lokal yang ada dalam wilayah tertentu. Radio komunitas tersebut lahir dengan tujuan mengaktualisasikan aspirasi mereka. Dinamika yang dimaksud tersebut tampak dari komunitas yang melatarbelakangi kelahiran radio komunitas. Latar belakang komunitas tersebut memang sangat beragam, mulai dari petani, pedagang pasar, warga di daerah rawan bencana, pengrajin gerabah, hingga komunitas yang bergerak di bidang pendidikan dan dakwah. Radio komunitas dihadirkan sebagai bagian dari pengelolaan ruang partisipasi masyarakat lokal.

Radio komunitas sebagai produk dari reformasi hingga saat ini masih menghadapi berbagai persoalan, yaitu persoalan manajemen, pendanaan, partisipasi masyarakat, serta dukungan dari pihak ketiga. Persoalan ini muncul dari keterbatasan-keterbatasan teknis yang dimiliki pengelola radio komunitas, serta regulasiregulasi dari pemerintah yang dianggap membatasi gerak radio komunitas untuk eksis dan berkembang.

Persoalan yang ditemukan dalam penelitian ini merupakan persoalan yang secara umum ditemukan dalam dua puluhradio komunitas yang menjadi subyek penelitian. Padahal setiap radio komunitas di Indonesia memiliki latar belakang geografis serta kondisi sosial-politik-ekonomi yang berbeda, termasuk tujuan yang spesifik, misalkan radio komunitas sebagai radio dakwah. Maka data yang ditemukan dalam penelitian ini dapatlah dianggap sebagai data awal untuk melanjutkan penelitian berikutnya dengan topik kajian dan subjek penelitian yang lebih spesifik. Selain itu, persoalan yang diidentifikasi dari hasil penelitian ini dapat digunakan sebagai peluang bagi kalangan akademis untuk melakukan kegiatan pengabdian pada masyarakat. Dengan demikian nilai-nilai keberlanjutan dapat diterapkan dengan lebih sinergis. 


\section{DAFTAR PUSTAKA}

Budiman, Ahmad. 2014. Penataan Lembaga Penyiaran Komunitas Dalam Akvitas Penyiaran Di Indonesia dalam Jurnal Politica Vol. 5 No. 1 Juni 2014. Diunduh di https://jurnal.dpr.go.id/ index.php/politica/article/view/335/269 tanggal 4 Desember 2017 pukul 15.10

Darmanto, A., Masduki, \& Kurniawan, P.A. Manajemen dan Produksi Radio Komunitas. Yogyakarta: Combine Resource Institution.

Imran, Hasyim Ali. 2015. Penelitian Komunikasi Pendekatan Kualitatif Berbasis Teks. Jurnal Studi Komunikasi dan Media Vol. 19 No. 1 Hal. 129-139

Kantor Berita Antara. 2008. Setiap Hari Terbit Lima Media Massa Baru Pasca-Reformasi. Diakses pada tautan https://www.antaranews.com/berita/93625/setiap-hari-terbit-lima-media-massa-barupasca-reformasi

Lubis, Mila. 2016. Radio Masih Memiliki Tempat di Hati Pendengarnya. Dikutip dari http:// www.nielsen.com/id/en/press-room/2016/RADIO-MASIH-MEMILIKITEMPAT-DI-HATIPENDENGARNYA.html

Masduki. 2007. Radio Komunitas Belajar dari Lapangan, Jakarta: Kantor Perwakilan Bank Dunia di Indonesia

Rianto, Puji. 2008. Studi Kasus. Dalam Metodologi Riset Komunikasi: Panduan untuk Melaksanakan Penelitian Komunikasi. Hal: 80-101. Yogyakarta: Balai Pengkajian dan Pengembangan Informasi (BPPI) Wilayah IV Yogyakarta dan Pusat Kajian Media dan Budaya Populer Yogyakarta.

Romli, Asep Syamsul M. 2009, Dasar-dasar Siaran Radio, Bandung: Nuansa.

Saddu, Cahyani. 2016. Hak Masyarakat dan Badan Publik atas Keterbukaan Informasi Publik. Jurnal Ilmu Hukum Legal Opinion Vol. 4 Edisi 1 Hal. 1-11

Wimmer, R. D. \& Dominic, J. R. 2011. Mass Media Research: An Introduction (9th edition). Boston: Wadsworth

\section{Regulasi}

Undang-Undang Republik Indonesia Nomor 32 Tahun 2002 Tentang Penyiaran Undang-Undang Republik Indonesia Nomor 40 Tahun 1999 Tentang Pers

Peraturan Pemerintah Republik Indonesia Nomor 51 Tahun 2005 tentang Penyelenggaraan Penyiaran Lembaga Penyiaran Komunitas 